\title{
CheMICAL COMPOSITION OF SCENTED EXTRACTS OBTAINED FROM CALENDULA OFFICINALIS BY THREE EXTRACTION METHODS
}

\author{
luis F. Salomé-Abarca, Ramón M. Soto-Hernández, Nicacio Cruz-Huerta \\ and Víctor A. GonzÁlez-Hernández ${ }^{1}$ \\ Postgrado en Recursos Genéticos y Productividad-Fisiología Vegetal, Colegio de Postgraduados-Campus Montecillo. \\ Montecillo, Texcoco, México. C.P. 56230 \\ ${ }^{1}$ Corresponding author: vagh@colpos.mx
}

\begin{abstract}
Hydrodistillation, organic solvent extraction, and enfleurage are common techniques for extracting essential oils from plant samples. One factor that influences the essential oil yield is the extraction method used. The aim of the study was to choose the best method for essential oil extraction from pot marigold flowers, based on oil yield, processing time, and number of extracted compounds, for research purposes focused on genotypic characterization. Yields of essential oils obtained by hydrodistillation, organic solvent extraction, and enfleurage were $0.9 \pm 0.1,6.7 \pm 0.2$ and $7.1 \pm 0.15 \mathrm{~g}$ of oil per $100 \mathrm{~g}$ of dry floral material, respectively. The method that provided the highest-quality oil (without pigments) was the hydrodistillation, which also contained the highest amount of non-polar compounds, but required a long time for processing many samples. Organic solvent extraction and enfleurage are faster for processing, but their extracted oils contain pigments. The most suitable technique for processing many samples in a short period of time was enfleurage because it provided an oil yield seven-fold higher than hydrodistillation and oil with less pigments than organic solvent extraction did. In addition, oil obtained by enfleurage contained the two main compounds in pot marigold flowers, $\alpha$-cadinene and $\delta$-cadinene.
\end{abstract}

Key words: essential oil, enfleurage, hydrodistillation, organic solvents extraction, yield.

Resumen: La hidrodestilación, extracción con disolvente orgánico y enfleurage son técnicas comunes para la extracción de aceites esenciales a partir de muestras vegetales. Un factor que influye en el rendimiento de la extracción de aceite esencial es el método utilizado. El objetivo de este estudio fue el de comparar tres métodos para la extracción de aceite esencial de capítulos de caléndula, con base en el rendimiento de aceite, el tiempo de procesamiento, y el número de compuestos extraídos, con fines de investigación centrados en caracterización genotípica de este tipo de materiales. Los rendimientos de los aceites esenciales obtenidos por hidrodestilación, extracción con disolvente orgánico y enfleurage fueron $0.9 \pm 0.1,6.7 \pm 0.2$ y $7.1 \pm 0.15$ g de aceite por 100 g de material floral seco, respectivamente. El método que proporciona el aceite de más alta calidad (sin pigmentos) fue la hidrodestilación, que también contuvo la mayor cantidad de compuestos no polares, aunque requiere mucho tiempo para procesar muchas muestras de forma simultánea. La extracción con disolventes orgánicos y enfleurage son más rápidos para su procesamiento, pero los aceites extraídos a través de ellos contienen pigmentos. La técnica más conveniente para procesar muchas muestras en un corto período de tiempo fue el enfleurage, porque proporcionó un rendimiento de aceite siete veces mayor que la hidrodestilación y un aceite con menos pigmentos que la extracción con disolvente orgánico. Además, el aceite obtenido por enfleurage contenía los dos compuestos principales en flores de caléndula, $\alpha$-cadineno y $\delta$-cadineno.

Palabras Clave: aceite esencial, enfleurage, extracción con solventes orgánicos, hidrodestilación, rendimiento.

I nflorescences and flowers of pot marigold (Calendula officinalis L.) are widely used for their anti-inflammatory, spasmodic, emmenagogue, cholagogue, sedative, sudorific and vulnerary properties, as well as for their bactericidal activity against Staphylococcus aureus and Streptococcus faecalis (Acosta-de la Luz et al., 2001). Pot marigold inflorescences reach their maximum volatile oil concentration at the full flowering stage $(0.97 \%)$ while the lowest concentration occurs at pre-flowering stages $(0.13 \%$; Okoh et al., 2007).

There are several methods for extracting essential oils, which differ in their characteristics. One of them is hydrodistillation wherein the aromatic plant material is immersed in two or threefold its weight of water, and then indirectly heated with steam coming out from a source outside the 
alembic, or directly heated by steam produced in the alembic (Lahlou, 2004).

Another method is the organic solvent extraction based on the principle that when a solid material is in contact with a solvent, the soluble components in the solid material are moved to the solvent. Therefore, when this extraction method is applied to plant material, the active soluble mass is non-selectively transferred to the solvent due to a concentration gradient (Singh, 2008).

Enfleurage is another extraction method for essential oils, which was designed to process large amounts of plant material. The extraction process can be carried out under cold or hot conditions. In the cold process mode, fat is spread on glass plates contained in wooden frames, leaving a clear margin around the edges. The absorption surface of the fat is increased by surface wood grooves previously made with a spatula. The fresh flowers are then spread over the fat and several frames can be piled up. After the fat has absorbed the essential oils from the flowers, the worn flowers are removed by hand. Fresh flowers are then extended again on the fat surface, and this procedure is repeated until the fat becomes completely saturated with oils.

In the hot fat maceration process, flowers or petals are dipped in the melted fat $\left(45\right.$ to $\left.60^{\circ} \mathrm{C}\right)$ so that extraction time is reduced to 1 to $2 \mathrm{~h}$, depending on plant species. After each dive, fat is filtered and the flowers or petals are removed. After 10 to 20 dives, the fat is cleaned from floral residues and water. In jasmine (Jasminum spp.), the whole enfleurage process lasts about 70 days, and each day the worn flowers are removed and the enfleurage boxes or plates are recharged with new flowers. One kilogram of fat should preferably be in contact with $3.0 \mathrm{~kg}$ of flowers for the entire enfleurage period (Handa, 2008). Since each method is based on different physical and chemical principles, it would be expected that their extracted essential oils will differ in specific compounds, even if the extracts are obtained from the same plant material.

Pot marigold is a plant of interest because of the therapeutic and cosmetic properties of its essential oils. Since this species has been little studied in Mexico, the proper extraction method for processing many samples simultaneously in research projects is unknown. In the Central Valley of Mexico, Palma et al. (2012) reported a wide floral diversity within a common variety of $C$. officinalis, and compared six floral genotypes (S1 to S6) contrasting in quantity and color of its inflorescences. In Mexico there is no information whatsoever about yield and chemical composition of essential oil from $C$. officinalis.

Therefore, the aim of the study was to determine the characteristics of the oils extracted from each of the three extraction techniques, in all cases applied to dry inflorescences. The comparison was based on oil yield, sample size, total required time for processing, and the number of compounds extracted by each technique.

\section{Materials and methods}

Pot marigold plants were grown under field conditions in Montecillo, Texcoco, State of Mexico (19 $19^{\circ}$ N, $98^{\circ} 53^{\prime}$ $\mathrm{W}$, altitude 2,250 m). The plant material for essential oils extraction consisted of a mixture of dry pot marigold inflorescences from the S4 genotype (which were dried at room temperature and shade conditions) obtained through several consecutive harvests done every week from June to July in 2012.

Hydrodistillation. The minimum amount of dry floral material $(7 \mathrm{~g})$ for oil extraction was established through this technique, by means of a Clevenger system. The plant material was placed inside a round bottom flask with $25 \mathrm{~mL}$ of distilled water and then boiled for $3 \mathrm{~h}$. After this time, the recovered emulsion of oil and water was extracted with dichloromethane $(3 \times 15 \mathrm{~mL})$, and then concentrated in a rotary evaporator Büchi ${ }^{\circledR}$ model R-114 under vacuum at 30 ${ }^{\circ} \mathrm{C}$ for evaporating the solvent as much as possible. The oil remaining in the flask was transferred to a $1.5 \mathrm{~mL}$ vial with a Pasteur pipette. Oil yield was calculated by multiplying by 100 the weight of the solvent-free oil and dividing by the weight of the initial dry weight. Three replicates were done in this test.

Organic solvent extraction. In this extraction method two solvents were tested, hexane and dichloromethane, both with or without sonication. In this method the minimum sample size was $4 \mathrm{~g}$ of dry plant material. This amount was added to $20 \mathrm{~mL}$ of each solvent (hexane or dichloromethane), then macerated for $5 \mathrm{~min}$. When sonicated, the macerated mixture was subjected to an ultrasonic bath Branson ${ }^{\circledR}$ model B-220 for $10 \mathrm{~min}$, in order to obtain the hexane and dichloromethane extracts with sonication. Non sonicated samples were used as controls. Afterwards the extracts were filtered and concentrated in a rotary evaporator Büchi ${ }^{\circledR}$ model R-114 under vacuum at $30^{\circ} \mathrm{C}$, to evaporating the solvent as much as possible. The oil remaining in the flask was transferred to a $1.5 \mathrm{~mL}$ vial with a Pasteur pipette and the rest of the solvent in the vial was allowed to evaporate at room temperature. Oil yield was calculated as in the previous method. Three replicates were performed in this test.

In order to select the most appropriate solvent, a sample of $20 \mathrm{mg}$ of extracted oil was dissolved in $500 \mu \mathrm{L}$ of the corresponding solvent, and then analyzed by TLC, on $2 \times 5$ $\mathrm{cm}$ silica gel plates $60 \mathrm{~F}_{254}$ with aluminum foil. The mobile phase was a toluene: ethyl acetate mixture in a 93:7 ratio.

Enfleurage. A micro extraction method for essential oils was previously established by combining the principles of cold enfleurage and hot enfleurage, and using karite (Butyrospermum paradoxa CF Gaertn.) vegetable fat as extractant. Karite fat was chosen because it is colorless and odorless, for preventing contamination with any other oil compound aside the plant material used. In this technique, $100 \mathrm{~g}$ of fat was heated to $40{ }^{\circ} \mathrm{C}$ until a liquid state without reaching 
boiling, and then $3 \mathrm{~g}$ of dry floral material were added for extraction at $40{ }^{\circ} \mathrm{C}$ during $20 \mathrm{~min}$. The liquid fat was poured onto a glass plate resting on ice to ensure a rapid solidification of the fat. Once the fat was solid, $5 \mathrm{~g}$ of dried floral material was added as it is done in cold enfleurage, in order to trap volatile compounds (which might have been lost during the hot process).

The cold fat extraction was left for 4 days, and then reheated to get a liquid fat again which was filtered with $50 \mathrm{~mL}$ of ethanol $(95 \%)$ at $60{ }^{\circ} \mathrm{C}$ for extracting the essential oil. This extract was centrifuged at 4,499.95 g for $5 \mathrm{~min}$ to remove detritus from fat. The ethanol extract was recovered and concentrated in a rotary evaporator Büchi ${ }^{\circledR}$ model R-114 under vacuum at $30{ }^{\circ} \mathrm{C}$. The extracted oil was transferred to a 1.5 $\mathrm{mL}$ vial with a Pasteur pipette for evaporating the remaining solvent. Oil yield was calculated in the same way as in the prior techniques. Three replicates were performed in this test. Statistical analysis. Analysis of variance and Tukey test $(\alpha=$ 0.05 ) for mean comparison were done for oil yield data, by using the SAS V 8.1 software.

Thin layer chromatography (TLC). The extraction capacity of two solvents (hexane and dichloromethane) used in the organic solvent extraction method was evaluated in terms of number of compounds extracted by TLC. A sample of 20 $\mathrm{mg}$ of oil was taken and dissolved in $500 \mu \mathrm{L}$ of the appropriate solvent. Compound separation by TLC was made on silica gel plates $60 \mathrm{~F}_{254}$ of $10 \times 10 \mathrm{~cm}$ with aluminum foil. Several applications of $15 \mu \mathrm{L}$ were made to obtain a good separation. The elution system was a mixture of toluene: ethyl acetate (93:7 ratio), and the plate was derivatized with $2 \%$ vanillin in ethanol and $10 \%$ sulfuric acid in ethanol at $110{ }^{\circ} \mathrm{C}$ during 5 min.

Gas chromatography coupled with mass spectroscopy (GC$M S)$. For comparing the extraction capacity of the three methods, in terms of the amount of extracted compounds in the oil, the three types of extract were analyzed by a Hewlett Packard HP 6890 Series ${ }^{\circledast}$ gas chromatograph coupled to a HP 5973 mass detector. This GC-MS system used a DBWAX column $/ 30 \times 0.250 \mu \mathrm{m}$ and $0.25 \mu \mathrm{m}$ thick stationary phase (Gardeli et al., 2008), using He as carrier gas with $99.9 \%$ purity, at $1 \mathrm{~mL} \mathrm{~min}^{-1}$; the oven temperature started at $40{ }^{\circ} \mathrm{C}$ and then increased by $9{ }^{\circ} \mathrm{C} \mathrm{min}-1$ until reaching a temperature of $220{ }^{\circ} \mathrm{C}$. Inlet temperature was $220^{\circ} \mathrm{C}$ in a splitless injector, and $280^{\circ} \mathrm{C}$ as interface temperature. For the mass detector, the ion source temperature was $230^{\circ} \mathrm{C}$ and $250^{\circ} \mathrm{C}$ at the quadrupole. Ionizing energy was $70 \mathrm{eV}$. Two replicates of the same concentration ( $1 \mathrm{mg}$ of essential oil per $\mu \mathrm{L}$ of dichloromethane) were injected. A mixture of $\mathrm{n}$-alkanes, toluene and oil was injected into the GC to calculating the Kovat's retention index, for each compound.

To identify the possible compounds, the ion spectrum of each compound was compared with the corresponding spectrum of the NIST library version 2002. The modified Kovat's Index (RI) was calculated with the Van de Dool and Kratz formula, where $C$ is the number of carbons in the compound, $\left(t^{\prime} R\right) x$ is the corrected retention time of one peak from the sample, $\left(t^{\prime}{ }_{R}\right) c+1$ is the corrected retention time of the alkane after the peak of interest, and $\left(t^{\prime}{ }_{R}\right) c$ is the corrected retention time of the alkane before the same peak. In this calculation, toluene was used as a low retention time compound, and the toluene retention time was inferred from the alkanes retention times and sample peaks (Hübschmann, 2009).

$$
R \mathrm{I}=100 \cdot C+100,\left(t^{\prime}-R\right) x-\left(t^{\prime}{ }_{R}\right) c-\left(t^{\prime}-{ }_{R}\right) c+1-\left(t^{\prime}{ }_{R}\right) c
$$

\section{Results}

The three extraction methods succeeded in extracting essential oils but differed in oil yield, number of compounds extracted, and sample size required, in addition to differences in their operational characteristics. Regarding their extraction capacities, the three methods showed a large variation to extract essential oil from pot marigold flowers, since oil yields oscillated from $0.9 \%$ for hydrodistillation to $7.1 \%$ for enfleurage (Table 1).

Both the organic solvent (OS) and enfleurage (ENF) methods produced pigmented extracts, compared to the extract obtained by hydrodistillation (HD). However, the enfleurage extract had much less pigments than the extract obtained by maceration in an organic solvent (Figure 1).

As shown in Table 1, the sample size was reduced to small amounts of dried flowers in the three techniques ( 7 , 4 and $8 \mathrm{~g}$ for HD, OS and ENF). In addition to the large differences in oil yield, these methods were also contrasting in processing times, which varied from $15 \mathrm{~min}$ to 120 hours and in the amount of extracted compounds $(19,15$ and 11, for HD, OS and ENF). Despite the large processing time for ENF, in our experience this method allowed to process about 24 samples per day, the same amount as with OS; while with only one HD system available, 2 samples could be processed per day.

Table 1. Comparison of three extraction techniques by their main operational traits and by the oil properties of their corresponding extracts. 'SS: sample size required for analysis; NEC: number of extracted compounds; PP: presence of pigments in the essential oil; PT: processing time per sample; NSPD: number of samples processed per day; na: not applicable. ${ }^{2}$ Qualitative scale for pigment presence in the oil: not present (np), high presence $(+++)$, low presence $(+) .{ }^{3}$ Different letters point out significant differences among oil yield means, according to the least significant difference (Tukey, $\alpha=0.05 ; n=3$ ).

\begin{tabular}{cccccc}
\hline Extraction technique & $\begin{array}{c}\mathrm{SS}^{1} \\
(\mathrm{~g})\end{array}$ & $\begin{array}{c}\text { Oil yield } \\
(\%)^{3}\end{array}$ & NEC & PP & $\begin{array}{c}\text { PT } \\
(\mathrm{h})\end{array}$ \\
\hline Hydrodistillation & 7 & $0.9^{\mathrm{c}}$ & 19 & $\mathrm{np}^{2}$ & 4 \\
Organic solvents & 4 & $6.7^{\mathrm{b}}$ & 15 & +++ & 0.25 \\
Enfleurage & 8 & $7.1^{\mathrm{a}}$ & 11 & + & 120 \\
DMSH $_{0.05}$ & na & 0.34 & na & na & na \\
\hline
\end{tabular}




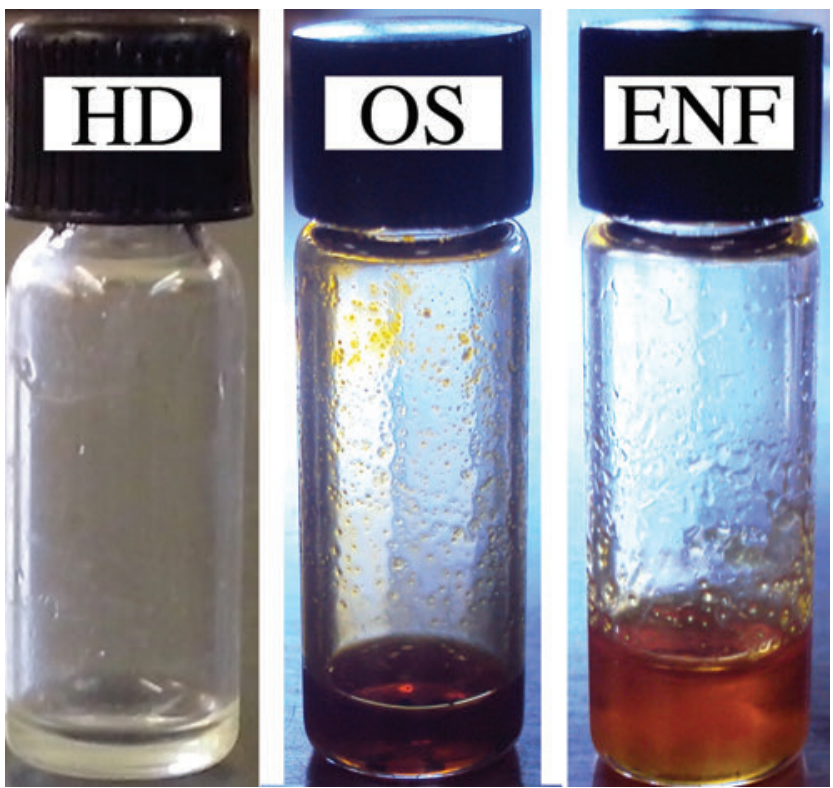

Figure 1. Vials containing essential oil extracted from pot marigold flowers, by three methods: Hydrodistillation (HD), Organic solvents extraction (OS), and Enfleurage (ENF).

In the essential oil obtained by HD, the GC-MS identified 19 compounds (Table 2), and only four of them had a quality less than $50 \%$. The total extraction time required by HD was only $4 \mathrm{~h}$ per sample, including the time for emulsion extraction and concentration in the rotary evaporator, but for simultaneously processing many samples the extraction would require the same amount of hydrodistillation systems, a fact that could be a limiting factor for most research laboratories.

For the organic solvent extraction (OS), dichloromethane was the best solvent when exposed to ultrasonic bath for 20 min, as measured by the number of bands detected by TLC in the extracts (Figure 2). With dichloromethane as organic solvent, the TLC test showed bands of greater intensity and thickness than with hexane. Organic solvent extraction is a rapid method (15 min per sample), but their extracts carry essential oils plus many pigments of a close polarity to the

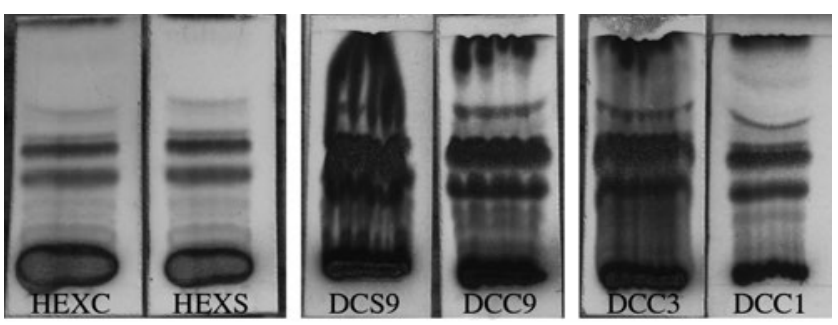

Figure 2. Thin layer chromatograms from essential oil extracts obtained with two organic solvents: hexane (HEX) with (C) and without (S) sonication; and dichloromethane with (C) and without sonication (S), making one (1), three (3) or nine (9) applications of the extract.
Table 2. Compounds detected in pot marigold essential oil obtained by hydrodistillation. ${ }^{1} \mathrm{Rt}$, Kovat's retention index. ${ }^{2} \mathrm{Q}$ ual, Reliability percentage.

\begin{tabular}{clccc}
\hline $\begin{array}{c}\text { Retention } \\
\text { time }\end{array}$ & \multicolumn{1}{c}{ Compound } & $\begin{array}{c}\text { Area } \\
(\%)\end{array}$ & ${ }^{1} R \mathrm{t}$ & ${ }^{2}$ Qual \\
\hline 15.46 & trans-p-mentha-2,8-dienol & 2.39 & 1,146 & 49 \\
15.84 & isoborneol & 3.79 & 1,149 & 62 \\
15.93 & borneol & 9.10 & 1,150 & 94 \\
16.24 & neryl acetate & 1.08 & 1,153 & 87 \\
16.76 & geranyl acetate & 3.80 & 1,158 & 91 \\
17.22 & $\alpha$-cadinene & 6.80 & 1,162 & 98 \\
17.28 & myrtenol & 1.04 & 1,163 & 93 \\
17.89 & cis-carveol & 0.96 & 1,167 & 98 \\
17.95 & p,a,a-trimethylbenzyl alcohol & 1.08 & 1,169 & 91 \\
18.08 & geraniol & 3.03 & 1,170 & 90 \\
18.90 & 3,5-di-tert-butylcatechol & 1.81 & 1,177 & 35 \\
19.66 & $\alpha$-selinene & 1.82 & 1,184 & 80 \\
20.43 & cariofilene oxide & 4.95 & 1,191 & 91 \\
21.38 & $\alpha$-cubebene & 3.84 & 1,200 & 46 \\
21.49 & 2,5,6-trimethylbenzimidazole & 1.37 & 1,201 & 47 \\
21.71 & Ledol & 2.06 & 1,202 & 99 \\
22.94 & $\delta$-cadinene & 19.06 & 1,791 & 93 \\
23.08 & $\alpha$-cadinol & 1.95 & 1,795 & 90 \\
24.46 & 2,3,5,6-tetramethyl-p-phenylene & 1.46 & 1,836 & 64 \\
\hline
\end{tabular}

solvent. In the oil extracted by this technique 15 compounds were identified by GC-MS, all of them with a quality higher than $60 \%$ (Table 3 ).

Oil yield obtained by enfleurage was sevenfold higher than that obtained by hydrodistillation (Table 1). In such extracts, there were 11 essential oils identified by GC-MS, with a minimal quality of $72 \%$ (Table 4 ). The two main

Table 3. Compounds detected in pot marigold essential oil obtained by organic solvent extraction. ${ }^{1} R$ t, Kovat's retention index. ${ }^{2}$ Qual, Reliability percentage.

\begin{tabular}{clccc}
\hline $\begin{array}{c}\text { Retention } \\
\text { Time }\end{array}$ & \multicolumn{1}{c}{ Compound } & $\begin{array}{c}\text { Area } \\
(\%)\end{array}$ & ${ }^{1} R \mathrm{t}$ & ${ }^{2}$ Qual \\
\hline 4.29 & $\alpha$-thujene & 3.91 & 480 & 94 \\
9.38 & methyl heptanone & 1.58 & 784 & 64 \\
11.65 & $(\mathrm{e}, \mathrm{e})$-2,4-heptadienal & 0.68 & 1,111 & 94 \\
12.00 & $\alpha$-cubebene & 1.27 & 1,114 & 97 \\
12.66 & copaene & 1.53 & 1,120 & 99 \\
12.92 & [r-(r*, r $\left.\left.^{*}\right)\right]-2,3$-butanediol & 1.07 & 1,123 & 80 \\
13.37 & $\beta$-cubebene & 2.34 & 1,127 & 95 \\
14.42 & cariofilene & 1.82 & 1,136 & 99 \\
15.91 & $\gamma$-murolene & 1.43 & 1,150 & 98 \\
16.24 & germacrene $d$ & 2.72 & 1,153 & 99 \\
16.47 & $\alpha$-murolene & 3.11 & 1,155 & 98 \\
17.00 & $\delta$-cadinene & 10.15 & 1,160 & 96 \\
17.06 & $\alpha$-cadinene & 7.15 & 1,160 & 98 \\
21.68 & ledol & 2.05 & 1,202 & 97 \\
23.01 & $\alpha$-cadinol & 0.68 & 1793 & 98 \\
\hline
\end{tabular}


Table 4. Compounds detected in pot marigold essential oil obtained by enfleurage. ${ }^{1} R \mathrm{t}$, Kovat's retention index. ${ }^{2} \mathrm{Q}$ ual, Reliability percentage.

\begin{tabular}{clccc}
\hline $\begin{array}{c}\text { Retention } \\
\text { time }\end{array}$ & \multicolumn{1}{c}{ Compound } & $\begin{array}{c}\text { Area } \\
(\%)\end{array}$ & ${ }^{1} R \mathrm{t}$ & ${ }^{2}$ Qual \\
\hline 3.69 & 3-methyl-3-buten-2-one & 0.63 & 389 & 91 \\
9.08 & 2,3-octanedione & 0.36 & 776 & 72 \\
9.35 & 6-metil-5-hepten-2-one & 0.21 & 784 & 80 \\
10.47 & nonanal & 0.16 & 813 & 98 \\
12.64 & benzaldehyde & 0.37 & 1,120 & 96 \\
13.34 & 3-cubebene & 0.30 & 1,127 & 95 \\
13.53 & 2,3-butanediol & 0.15 & 1,128 & 80 \\
16.20 & germacrene d & 0.27 & 1,153 & 99 \\
16.43 & $\alpha$-murolene & 0.42 & 1,155 & 96 \\
16.95 & -cadinene & 4.42 & 1,159 & 96 \\
17.22 & $\alpha$-cadinene & 6.80 & 1,162 & 98 \\
\hline
\end{tabular}

components present in the essential oil obtained here from pot marigold flowers ( $\delta$-cadinene and $\alpha$-cadinene $)$.

\section{Discussion}

The oil yield obtained here by hydrodistillation $(0.90 \pm$ 0.1 ) is similar to the yield previously reported of $0.97 \%$ for hydrodistillation in pot marigold flowers (Okoh et al., 2007), and $\alpha$-thujene as the major compound (Okoh et al., 2008). The sample sizes used here for extracting essential oil from pot marigold flowers for research purposes, were good enough to measure oil yield and for detecting variation in their composition. These sample sizes are much smaller compared to the sizes reported in other plant species, such as Thymus vulgaris (Golmakani and Rezaei), Ferula assa-foetida (Khajeh et al., 2005) and Juniperus communis (Pourmortazavi et al., 2004), which were 60, 40 and $80 \mathrm{~g}$ of dry plant material, respectively. In contrast, other researchers reported enfleurage as the technique producing the largest number of compounds in extracts obtained from jasmine flowers, compared to HD (Paibon et al., 2011). Therefore, the effectiveness of essential oil extraction techniques would also depend on plant species.

Organic solvent extraction, even though it is a useful technique for processing many samples in a short period of time, is limited by the large amount of pigments trapped in their extracts. Such pigments can produce phytochemical interference when analyzed by GC-MS, because they might plug the column due to their lack of volatility and high molecular weight. Samples containing a high concentration of pigments have to be much diluted before being injected into the GC. Pigments could also interfere with pharmaceutical applications.

Enfleurage has been also reported by other researchers as the best method for reaching the highest oil yield. For example, in extracts obtained by hot enfleurage from Polianthes tuberosa, an oil yield of $6.58 \%$ was reported, which represented an increase of 236 times compared to $0.03 \%$ obtained by organic solvent extraction (Rakthaworn et al., 2009).

Regarding the type of identified compounds in the essential oil from pot marigold flowers, it is interesting to note that $\alpha$-cadinene and $\delta$-cadinene were the main compounds in extracts from the three extraction techniques compared here, thus indicating that they are the major components of the non-polar fraction of pot marigold essential oil. In Brazil, Gazim et al. (2008) also reported $\delta$-cadinene as the major component of the pot marigold essential oil.

In summary, the three methods evaluated here are able to extract essential oil from dried pot marigold flowers, but they have large differences in oil yield, processing time and oil quality, thus influencing the essential oil performance. For comparison of many plant samples in research projects, enfleurage is the most convenient method because it allows processing many plant samples simultaneously in a short time, and because it can extract the main non-polar compounds to characterize plant genotypes or harvesting dates, as Palma et al. (2012) did for analyzing flavonoids content in this species.

The differences in physical and chemical composition of the volatile and non-volatile fraction of the oils obtained by these three techniques could be associated to differences in physical and chemical principles that govern each technique. For example, hydrodistillation can only extract volatiles carried by water vapor so that its extract does not contain pigments, then making this technique a very selective one (Handa, 2008).

In contrast, the organic solvent extraction is a non-selective method because it would extract any compound with a polarity close to that of the solvent (Singh, 2008). Meanwhile, enfleurage is based on extraction of fat soluble compounds, such as oils and pigments, followed by an extraction of essential oils with polarity related to the solvent, such as ethanol (Handa, 2008). Therefore, most pigments also remain trapped in the body fat used for extraction, because they are retained by fat with a higher strength than essential oils.

\section{Acknowledgments}

To CONACYT-México for the scholarship granted to the first author for obtaining his master's degree, and to the peer reviews done by the anonymous reviewers who helped us to improve this manuscript.

\section{Literature cited}

Acosta-de la Luz L., Rodríguez-Ferradá C. and Govín-Sánchez E. 2001. Instructivo técnico de Calendula officinalis. Revista $\mathrm{Cu}$ bana de Plantas Medicinales 6:23-27.

Gazim Z.C., Moraes-Rezende C., Fraga S.R., Prado-Días F.B., Vataru C. and García-Cortez D.A. 2008. Analysis of the essential 
oils from Calendula officinalis growing in Brazil using three different extraction procedures. Revista Brasileira de Ciências Farmacêuticas 44:391-395.

Gardeli C., Vassiliki P., Athanasios M., Kibouris T. and Komaitis. 2008. Essential oil composition of Pistacia lentiscus L. and Myrtus communis L.: Evaluation of antioxidant capacity of methanolic extracts. Food Chemistry 107:1120-1130.

Handa S.S. 2008. An overview of extraction techniques for medicinal and aromatic plants. In: Handa S.S., Singh S.P., Longo K.G. and Rakesh D.D. Eds. Extraction Technologies for Medicinal and Aromatic Plants, pp. 21-52, International Centre for Science and High Technology, ICS-UNIDO, Trieste.

Hübschmann H.J. 2009. Handbook of GC/MS, Fundamentals and Applications. Second edition. Ed. Wiley-VCH Verlag GmbH \& Co. KGaA, Weinheim.

Khajeh M., Yamini Y., Bahramifar N., Sefidkon F. and Pirmoradei M. R. 2005. Comparison of essential oils compositions of Ferula assa-foetida obtained by supercritical carbon dioxide extraction and hydrodistillation methods. Food Chemistry 91:639-644.

Golmakani M. T. and Rezaei K. 2008. Comparison of microwaveassisted hydrodistillation with the traditional hydrodistillation method in the extraction of essential oils from Thymus vulgaris L. Food Chemistry 109:925-930.

Lahlou M. 2004. Methods to study the phytochemistry and bioactivity of essential oils. Phytotherapy Research 18:435-448.

Okoh O.O., Sadimenko A.A. and Afolayan A.J. 2007. The effects of age on the yield and composition of the essential oils of $\mathrm{Ca}$ lendula officinalis. Journal of Applied Sciences 7:3806-3810.

Okoh O.O., Sadimenko A.P., Asekun O.T. and Afolayan A.J. 2008.
The effects of drying on the chemical components of essential oils of Calendula officinalis L. African Journal of Biotechnology 7:1500-1502.

Paibon W., Yimnoi C.A., Tembab N., Boonlue W., Jampachaisri K., Nuengchamnong N., Waranuch N. and Ingkaninan K. 2011. Comparison and evaluation of volatile oils from three different extraction methods for some Thai fragrant flowers. International Journal of Cosmetic Sciences 33:150-156.

Palma T.M., González V.A.H. and Soto R.M.H. 2012. Variación genética y ambiental en el contenido de flavonoides en capítulos de calendula. In: Cruz-Izquierdo S., Ayala-Garay O. J., Cruz-Huerta N., Ramírez-Ramírez I. y Martínez-Villegas E. Eds. Avances de Investigación 2012. Postgrado en Recursos Genéticos y Productividad-Genética. Colegio de Postgraduados, Campus Montecillo. Montecillo, Texcoco.

Pourmortazavi S.M., Baghaee P. and Mirhosseini M.A. 2004. Extraction of volatile compounds from Juniperus communis L. leaves with supercritical fluid carbon dioxide: comparison with hydrodistillation. Flavour and Fragrance Journal 19:417-420.

Rakthaworn P., Dilokkunanant U., Sukkatta U., Vajrodaya S., Haruethaitanasan V., Pitpiangchan P. and Punjee P. 2009. Extraction methods for tuberose oil and their chemical components. Kasetsart Journal (Natural Sciences) 43:204-211.

Singh J. 2008. Maceration, percolation and infusion techniques for the extraction of medicinal and aromatic plants. In: Handa S.S., Singh S.P., Longo K.G. and Rakesh D.D. Eds. Extraction Technologies for Medicinal and Aromatic Plants, pp. 67-82, International Centre for Science and High Technology, ICS-UNIDO, Trieste.

Received: April 1st, 2014

Accepted: June 21st, 2014 